\title{
The effect of crop residues on soil nitrogen dynamics and wheat yield
}

\begin{abstract}
The effects of different kinds of crop residues on cereal yield and nitrogen uptake have not been studied. A two-year (2008-2010) field experiment was aimed to study the effect of four crop (cotton, alfalfa, wheat and maize) residues with different $C: N$ ratios and compare them with pure urea and a control treatment, on soil $\mathrm{N}$ concentration (as nitrate+ammonia) and total $\mathrm{N}$ accumulation in the leaves and stem of wheat (cv. N8019, a high N-demanding cultivar). For this purpose, immobilization was avoided by adding $\mathrm{N}$ as urea to residues based on their $\mathrm{C}: \mathrm{N}$ ratio and nitrogen index, which was established at $90 \mathrm{Kg} \mathrm{N} . \mathrm{ha}^{-1}$. Soil and plant nitrogen were measured in six phenological stages. The maximum yield difference between residues and the control treatment was 1.7 ton $\mathrm{ha}^{-1}$ in the alfalfa residue. The highest nitrate and ammonia concentration in the soil $\left(74.1 \mathrm{~kg} \mathrm{ha}^{-1}\right)$, the greatest consistency between nitrate and ammonia release with crop demand (from tillering to stem elongation) and the highest increase in yield per $1 \mathrm{~kg}$ of added $\mathrm{N}\left(29.14 \mathrm{~kg}\right.$ grain $\left.\mathrm{ha}^{-1} \mathrm{~kg}^{-1} \mathrm{~N}\right)$ also characterized the alfalfa residue. Overall, treatments had affected wheat grain yield, leaf area index and 1000-grain weight, but did not affect grain number spike-1. The highest grain yield ( 7.25 ton $\left.^{-1} \mathrm{~h}^{-1}\right)$ and 1000 -grain weight $(50.36 \mathrm{~g})$ were also obtained when alfalfa residue was applied, although all residues resulted in higher yield than the control plot. Wheat residues did not perform well compared to other residues. Since other residues performed worse than alfalfa but performed better than the wheat residue, their use in the field should be carefully considered.
\end{abstract}

Keywords: Internal input; Sustainability; Decomposition; Yield component; Residue management
Volume I Issue I - 2014

\author{
Behnam Kamkar,' Farideh Akbari,' Jaime A \\ Teixeira da Silva, ${ }^{2}$ Seyyed Alireza Movahedi \\ Naeini ${ }^{3}$ \\ 'Department of Agronomy, Gorgan University of Agricultural \\ Science and Natural Resources (GUASNR), Iran \\ ${ }^{2} \mathrm{PO}$ Box 7, Miki-cho post office, Ikenobe 30I I-2, Kagawa-ken, \\ 761-0799, Japan \\ ${ }^{3}$ Department of Soil Science, Gorgan University of Agricultural \\ Science and Natural Resources (GUASNR), Iran
}

\begin{abstract}
Correspondence: Behnam Kamkar, Department of Agronomy, Gorgan University of Agricultural Science and Natural Resources (GUASNR), Plant Production Faculty, Basij Square, Pardis No 2, 49I89-43464, Iran, Tel +98- I7I-4427060, Fax +9817|-4420438, Email kamkar@gau.ac.ir
\end{abstract}

Received: April 18, 2014 | Published: May 14, 2014

\section{Introduction}

Plant residues have an important role as soil and water-protecting factors. In Iran, in recent decades, there has been an increasing interest in managing crop residues using practices other than burning or removing them from the field. ${ }^{1}$

Burning and removal of residues not only causes a direct loss of nutrients in soils but also deprives the soil of carbon or organic matter, which is important for improving soil structure and providing life to the soil by acting as a substrate for various microbes and biota. ${ }^{2}$ Also, the removal of crop residues from an agricultural system will increase the potential for increased soil erosion and/or negative effects on environmental quality. ${ }^{3-5}$ Therefore, management of a crop residue can contribute to increased nutrient cycling and greater crop yields ${ }^{4,6,7}$ and also has an important role in reducing soil erosion and maintaining yield. ${ }^{8}$ By selecting crop rotation and/or management practices such as minimum tillage to reduce soil disturbance and/or increase the amount of residue returned to the soil, soil organic carbon and nitrogen can be increased in the system. ${ }^{6,8,9}$ The rate of decomposition and $\mathrm{N}$ mineralization increases by increasing the quality of a plant residue. ${ }^{10,11}$ Although the quality of a residue is an important factor to determine the $\mathrm{C}$ and $\mathrm{N}$ mineralization rate, residue management is a factor affecting this process. ${ }^{12}$

The amount of nutrients released during the decomposition of a crop residue is very important in both organic and conventional farming systems; in the former, it has a decisive influence on crop yield and in the latter, it could lead to a reduction in mineral fertilizer application. $^{13,14}$ Based on other reports, the incorporation of crop residues increased the grain yield more than treatments in which residues were removed. Where crop residues were incorporated also produced significantly more grains spike ${ }^{-1}$ and 1000-grain weight, which might have resulted in higher yield. ${ }^{15-19}$ Similarly, ${ }^{20,21}$ reported an increase in cereal grain and stover yield when crop residues were incorporated, unlike treatments where residues were removed. However, despite many important benefits of crop residues, some of their effects can vary. For instance, growth and yield of corn is reduced when winter wheat residues are used, ${ }^{22,23}$ especially when heavy wheat residues were used. ${ }^{24,25}$ A reduction or increase in yield induced by different crop residues and their management practices depend on a complex interaction between soil, plant and environmental factors, as conceptualized by Kumar et al., ${ }^{1}$ \& Kamkar et al. ${ }^{26}$ Although many studies have been conducted with the aim of examining the effects of $\mathrm{N}$ fertilizers on cereal yield, ${ }^{27}$ the effects of different kinds of crop residues and their management practices on cereal yield have not been studied and compared. For example, Rasmussen et al., ${ }^{28}$ found that residue removal by burning did not affect wheat yield in winter wheat-fallow rotation compared with incorporating the residues by ploughing.

This study aimed to compare the effects of different crop residues (with various $\mathrm{C}: \mathrm{N}$ ratios) on grain yield and yield components of wheat (N8019 variety), plant tissue nitrogen content and soil $\mathrm{N}$ mineralization.

\section{Material and methods}

A two-year field experiment (2008-2010) was carried out on wheat (cv. N8019) at Gorgan University of Agricultural Sciences 
and Natural Resources Farm, Iran (36 $86^{\prime}$ latitude and $54^{\circ} 27$ longitude at an altitude of around $13 \mathrm{~m}$ above sea level). This cultivar is a high-yielding cultivar with a high $\mathrm{N}$ demand. The climate of the area is temperate, with a mean annual rainfall of $421.7 \mathrm{~mm}$, most of the rain falling between September and January, and a mean annual air temperature of $18.5^{\circ} \mathrm{C}$ with a minimum of $9.5^{\circ} \mathrm{C}$ in winter and a maximum of $29.5^{\circ} \mathrm{C}$ in summer. Temperature records for the two study years are presented in (Figure 1A). There were no pronounced differences in temperature between the growing season in 2008-2009 and 2009-2010, particularly during the reproductive and grain-filling period (March, April and May). Rainfall over the reproductive period of wheat was higher in 2009-2010 (Figure 1B). Soil samples were mixed thoroughly to obtain a composite sample for each plot. Soil of the area was loamy - clay-silty with a pH of 7.8 and sand, silt, and clay contents of 10,52 and $38 \%$, respectively at 0 to $30 \mathrm{~cm}$ depth. Organic $\mathrm{C}$ and organic $\mathrm{N}$ were 0.95 and $0.1 \%$ respectively.
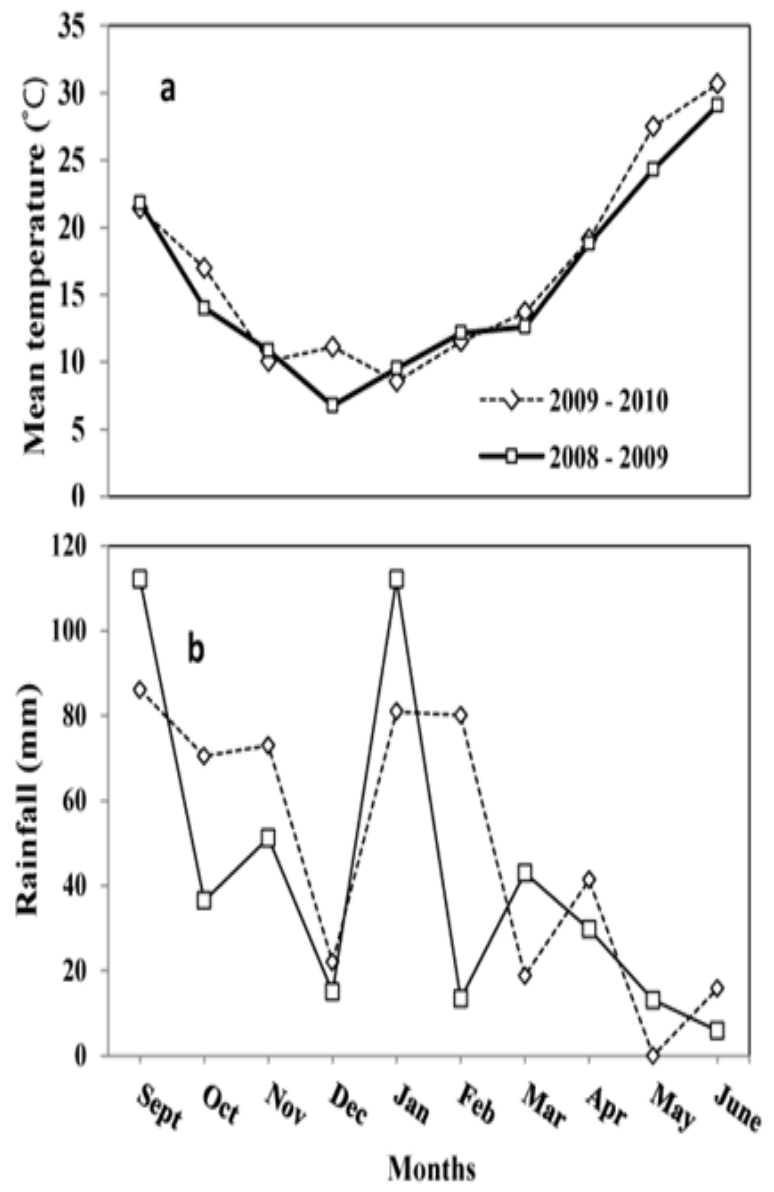

Figure I Average monthly temperature $(A)$ and rainfall $(B)$ during the two study years according to recorded data by the nearest meteorological station (Hashemabad).

The experiment was conducted as a complete randomized block (CRB) design with four replicates. In the first year of the experiment, a total of six treatments (four residues with different $\mathrm{C}: \mathrm{N}$ ratios including cotton, alfalfa, wheat and corn), pure urea (90Kg urea ha 1) and a control treatment (without residue or fertilizer application) were considered. All residue-related treatments were incorporated as $<5 \mathrm{~mm}$ particles. The rate of residue and the amount of $\mathrm{N}$ needed to avoid immobilization were determined by determination of the C:N ratio and $\mathrm{N}$ index to provide $90 \mathrm{Kg} \mathrm{N} \mathrm{ha}{ }^{-1} .^{29}$ The C:N ratio for cotton, corn, wheat and alfalfa were as $32.27,49.62,60.47$ and 21.78 respectively. Total organic carbon (TOC) and total nitrogen content (TN) were measured by the Walkley et al., ${ }^{30}$ and the Kejldahl methods $^{31}$ respectively.

The amount of cotton, maize, wheat and alfalfa residues to provide $90 \mathrm{Kg} \mathrm{N} \mathrm{ha}^{-1}$ were calculated as the $\mathrm{N}$ index with regard to the $\mathrm{C}: \mathrm{N}$ ratio of residues as well as required mineral $\mathrm{N}$ fertilizer to prevent immobilization. ${ }^{32}$ Then, chopped residues plus a calculated amount of urea fertilizer for each residue treatment (to prevent $\mathrm{N}$ immobilization by microbial community, as calculated by Barbarick ${ }^{32}$ and pure urea in other treatments were incorporated into soil by a six-rows disk at a depth of $30 \mathrm{~cm}$. The amount of residue incorporated into soil was 6467 , 5988,5622 , and $5972 \mathrm{Kg} \mathrm{ha}^{-1}$ for cotton, maize, wheat and alfalfa, respectively and the amount of mineral $\mathrm{N}$ fertilizer required for these residues to inhibit microbial immobilization was calculated as 66.16 , 75,100 and $58.33 \mathrm{Kg} \mathrm{ha}^{-1}$, respectively. The $3 \times 4 \mathrm{~m}$ plots were handseeded to obtain a target density of 330 plants $\mathrm{m}^{-2}$ with a row spacing of $20 \mathrm{~cm}$ and $1.5 \mathrm{~cm}$ on the rows (including 16 rows). Wheat was cultivated on January 1, 2008 and harvested on June 1; residues were brought from the field, which was left fallow until January 1, 2009 when the cultivation was carried out again without the incorporation of any residues or without the application of any fertilizer. Grains were disinfected by carboxin thiram (antifungal agent) before cultivation. Cultures were irrigated twice during the growth season, as needed.

Phenological stages, including tillering, stem elongation, booting, anthesis, physiological maturity and harvesting maturity were recorded by the Zadox coding method ${ }^{33}$ during the growth season using 15 tagged plants. Total mineralized nitrate + ammonia in the soil (as kg ha-1) during the wheat-growing season (2008-2010) was determined by an extracted solution using $2 \mathrm{M} \mathrm{KCl}$.

Leaf area was measured from least five plants on each plot by a digital leaf area meter (Delta T Device, UK). The two central rows of each plot were harvested by hand in early June in both growing seasons (2008-2010) to determine grain number ear ${ }^{-1}, 1000$-grain weight (TGW) and total grain yield. The same measurements were repeated in the second year. Data from both years were combined and statistically analyzed by SAS software ${ }^{34}$ and means were compared by the LSD test $(P<0.05)$. Post-ANOVA analysis also was performed as needed.

\section{Results and discussion}

A summary of the analysis of variance results for grain yield, grain spike ${ }^{-1}, \mathrm{TGW}$, leaf area index (LAI), and nitrate and ammonia concentrations are given in (Table 1) (these data are related to two year). The results of compound analysis of the two-year experiment showed that the effect of year on the studied characteristics was significant (Table 2), so data of each year was analyzed separately for all characteristics. Treatments had significant effects on wheat grain yield, TGW and LAI for both years (Tables $2 \&$ Table 3 ).

The grain yield obtained in different treatments for both years (Table 2) was significantly different between the control treatment (with the lowest yield) and the alfalfa treatment (as the highest value). The biggest difference in grain yield was observed between the control and alfalfa treatment in 2009 (alfalfa 24\% higher), which had the lowest $\mathrm{C}: \mathrm{N}$ ratio after the urea treatment. This was also true 
for 2010 (alfalfa was $31 \%$ higher). The least increase in yield relative to the control based on a pooled mean from both years was in the urea treatment (Table 2), while the highest was in alfalfa followed by, maize, cotton and wheat in this descending order. Among the residues used, alfalfa residue had the highest $\mathrm{N}$ content (Figure 3). Although wheat yield in all treatments in the second year (without incorporation of residues or application of fertilizer) decreased relative to the first year and although the greatest decrease was seen when the wheat residue was used (31\%), the increment in yield relative to the control in the second year was higher in all treatments (Table 2). Regression analysis of the $\mathrm{C}: \mathrm{N}$ ratio of different residues versus corresponding wheat grain yield revealed no significant relationship $\left(\mathrm{R}^{2}=0.094\right)$. Our finding showed that not only the $\mathrm{C}: \mathrm{N}$ ratio is solely a reliable factor in view of decomposition, but it highlights that there may be other factors other than the $\mathrm{C}: \mathrm{N}$ ratio that affect analysis and interpretation of residue effects on yield. For instance, in this research in both years, maize residues (with a C:N ratio of 49.6) increased grain yield more than cotton residues (with a $\mathrm{C}: \mathrm{N}$ ratio of 32.27).

Table I Analysis of variance for grain yield (ton ha-1), number of grains spike ${ }^{-1}$, 1000-grain weight (TGW)(g), leaf area indexb (LAI) and total mineralized nitrate + ammonia in treatments used in the experiment base on two years data

\begin{tabular}{|c|c|c|c|c|c|c|}
\hline \multicolumn{7}{|l|}{ Mean square } \\
\hline Source of variation & d.f & $\begin{array}{l}\text { Grain yield } \\
\left(\text { ton } \mathrm{ha}^{-1}\right)\end{array}$ & $\begin{array}{l}\text { No. of grains } \\
\text { spike }\end{array}$ & TGW(g) & LAI & $\begin{array}{l}\text { Total mineralized nitrate }+ \\
\text { ammonia }\left(\mathrm{kg} \mathrm{ha}^{-1}\right)\end{array}$ \\
\hline Year & I & $75.5 I^{*}$ & $|356.8|^{*}$ & $283.77^{*}$ & $35.57^{*}$ & $|129| .6 \mid *$ \\
\hline Replication xyear & 6 & $1.33^{\text {ns }}$ & $20.1^{\text {ns }}$ & $11.64^{\mathrm{ns}}$ & $0.49^{\text {ns }}$ & $223.74^{\text {ns }}$ \\
\hline Residue & 5 & $1.24^{\mathrm{ns}}$ & $9.24^{\text {ns }}$ & $5.28^{\text {ns }}$ & $0.44^{\mathrm{ns}}$ & $686.83^{\text {ns }}$ \\
\hline Residuexyear & 5 & $1.1 I^{\mathrm{ns}}$ & $10.96^{\mathrm{ns}}$ & $16.52^{*}$ & $0.01 *$ & $773.81^{\mathrm{ns}}$ \\
\hline Error & 30 & 0.7 & 7.41 & 3.82 & 0.27 & 392.1 \\
\hline
\end{tabular}

*significant at $\mathrm{P} \leq 0.05$ according to the Least Significant Difference Test. Ns, not significant

Table 2 Mean comparison for grain yield (ton ha- ${ }^{-1}$ ), grains spike-1 and 1000-grain weight (TGW) for each year separately and two years(2008-2010) mean

\begin{tabular}{|c|c|c|c|c|c|c|c|c|c|}
\hline \multirow[t]{2}{*}{ Treatment } & \multicolumn{3}{|c|}{ Grain yield(ton $\left.\mathrm{ha}^{-1}\right)$} & \multicolumn{3}{|c|}{ Grains spike-I } & \multicolumn{3}{|c|}{$\operatorname{TGW}(\mathrm{g})$} \\
\hline & 2009 & 2010 & Mean & 2009 & 2010 & Mean & 2009 & 2010 & Mean \\
\hline Cotton & 7. 3ab(5.7)* & $5.4 \mathrm{ab}(20)$ & $6.6 \mathrm{~b}(15)$ & $29.69 a$ & $23.06 a$ & $26.5 \mathrm{la}$ & $48.7 \mathrm{~b}$ & $46.26 \mathrm{a}$ & $47.45 \mathrm{a}$ \\
\hline Maize & $7.7 \mathrm{ab}(\mathrm{II})$ & $5.6 \mathrm{ab}(22)$ & $6.8 \mathrm{a}(19)$ & $33.45 \mathrm{a}$ & $20.55 a$ & $27 a$ & $51.52 \mathrm{ab}$ & $46.42 a$ & $48.97 \mathrm{ab}$ \\
\hline Wheat & $7.6 \mathrm{ab}(10)$ & $5.2 \mathrm{ab}(17)$ & $6.4 \mathrm{ab}(12)$ & $32.8 \mathrm{a}$ & $21.7 \mathrm{Ia}$ & $27.2 \mathrm{a}$ & $49.7 \mathrm{ab}$ & $45.56 \mathrm{ab}$ & $47.6 \mathrm{ab}$ \\
\hline Alfalfa & $8.6 a(24)$ & $5.9 a(3 I)$ & $7.25 \mathrm{a}(27)$ & $31.43 a$ & $20.29 a$ & $25.8 \mathrm{a}$ & $53.07 \mathrm{a}$ & $47.66 \mathrm{a}$ & $50.36 a$ \\
\hline Urea & $8 . \operatorname{lab}(17)$ & $4.9 \mathrm{ab}(8)$ & $6.3 \mathrm{ab}(10)$ & $33.87 \mathrm{a}$ & $21.01 \mathrm{a}$ & $27.4 a$ & $52.6 \mathrm{a}$ & $43.8 \mathrm{lb}$ & $48.2 \mathrm{ab}$ \\
\hline Control & $6.9 \mathrm{~b}(0)$ & $4.5 b(0)$ & $5.7 \mathrm{~b}(0)$ & $29.04 a$ & $20.13 a$ & $24.5 \mathrm{a}$ & $48.67 \mathrm{~b}$ & $45.37 \mathrm{ab}$ & $47.1 \mathrm{~b}$ \\
\hline 2009 & --- & .-- & $7.79 a$ & ..- & -.- & $21.26 \mathrm{a}$ & --- & -.- & $50.7 \mathrm{la}$ \\
\hline 2010 & --- & --- & $5.29 \mathrm{~b}$ & --- & --- & $21.12 \mathrm{a}$ & --- & --- & $45.84 \mathrm{~b}$ \\
\hline
\end{tabular}

*Means within each column with a similar letter are not significantly different at $\mathrm{P} \leq 0.05$, according to the least significant difference test. The values in parentheses show differences in percentage relative to the corresponding control treatment.

Table 3 Mean comparison for leaf area index (LAl) and nitrate+ammonia concentration in the soil (kg ha-1) for each year separately and two years (2008-20 I0) mean

\begin{tabular}{lllll}
\hline Treatment & LAI & & & Nitrate+ammonia concentration(kg ha $\left.{ }^{-1}\right)$ \\
\hline Cotton & $\mathbf{2 0 0 9}$ & $\mathbf{2 0 1 0}$ & Mean & Mean \\
Maize & $5.95 \mathrm{a}^{*}$ & $3.89 \mathrm{a}$ & $4.92 \mathrm{a}$ & $66.07 \mathrm{ab}$ \\
Wheat & $5.52 \mathrm{ab}$ & $3.85 \mathrm{a}$ & $4.69 \mathrm{ab}$ & $57.88 \mathrm{ab}$ \\
Alfalfa & $4.65 \mathrm{ab}$ & $3.45 \mathrm{ab}$ & $4.55 \mathrm{abc}$ & $54.39 \mathrm{ab}$ \\
Urea & $4.85 \mathrm{~b}$ & $3.63 \mathrm{a}$ & $4.24 \mathrm{bcd}$ & $74.1 \mathrm{a}$ \\
control & $4.75 \mathrm{~b}$ & $3.03 \mathrm{~b}$ & $3.13 \mathrm{~cd}$ & $68.52 \mathrm{ab}$ \\
2009 & & & $5.26 \mathrm{a}$ & $49.79 \mathrm{~b}$ \\
2010 & & & $3.54 \mathrm{~b}$ & $109.94 \mathrm{a}$ \\
\end{tabular}

*Means within each column with a similar letter are not significantly different at $\mathrm{P} \leq 0.05$, according to the least significant difference test. 
Although we did not use any N-resource input in the second year, alfalfa and maize residue treatments had higher grain yield than the control treatment. Grain yield was significantly affected by the type of residue. There was no significant difference in the amount of grains per spike between residue treatments and urea in the control treatment (Table 2).

Maize and alfalfa residue treatments resulted in the highest TGW in both years compared with other treatments, which can be attributed to higher $\mathrm{N}$ supply by these residues $(57.8$ and $74.1 \mathrm{Kg}$ $\mathrm{ha}^{-1}$, respectively). Since $\mathrm{N}$ has considerable effects on grain filling, we can conclude that the release of $\mathrm{N}$ from maize residues prolonged the supply of $\mathrm{N}$ in this period and resulted in an increase in TGW. In the second year, yield was more affected than grain spike ${ }^{-1}$ by TGW; moreover, grain spike ${ }^{-1}$ was not affected by different applied treatments (Table 2). This was also obvious for the means in both years (Table 2). This might correspond to lower leaf area (Table 3) which restricts the source supply to provide adequate assimilates to fill grains. TGW was generally lower in 2009-2010 than in 2008-2009 (Table 2). There was a significant difference in LAI between residue treatments and urea compared to the control treatment in both years (Table 3). As development progressed, LAI increased when cotton, maize and wheat residues were decomposed in the anthesis stage more than in treatments with urea and alfalfa residues (values not shown). This indicates the importance of consistency between the release of $\mathrm{N}$ by crop residues and crop demand.

Leaf and stem $\mathrm{N}$ content in wheat plants was approximately the same for alfalfa and cotton residues (44.52 and $42.77 \mathrm{~g} \mathrm{~N} \mathrm{~kg}^{-1}$ dry matter (DM), respectively) (Figure 2), but significantly greater than in the wheat residue treatment $\left(38.55 \mathrm{~g} \mathrm{~N} \mathrm{~kg}^{-1} \mathrm{DM}\right)$. Alfalfa and cotton residues provided the most mineralized $\mathrm{N}$ as nitrate and ammonia in soil (74.1 and $66.07 \mathrm{~kg} \mathrm{ha}^{-1}$, respectively) (Table 3). Greater $\mathrm{N}$ availability when alfalfa and cotton residues are incorporated and decomposed can be attributed to a higher $\mathrm{N}$ content despite approximately the same percentage $\mathrm{C}$ in their foliar parts (Figure 3). Alfalfa and cotton residues are rapidly decomposed because of their lower $\mathrm{C}: \mathrm{N}$ ratio (21.78 and 32.27 , respectively) and low percentage lignin (7 and 1.4\%), which can result in making $\mathrm{N}$ more available to plants compared to other residues. The highest values of measured mineralized $\mathrm{N}$ as nitrate and ammonia in soil were from residues which had the lowest $\mathrm{C}: \mathrm{N}$ ratio. Although the $\mathrm{C}: \mathrm{N}$ ratio has long been known to be a major factor in controlling the rate from which $\mathrm{N}$ is released from crop residues, ${ }^{1,35}$ in the present study, mineralized soil $\mathrm{N}$ was poorly correlated with the residue's $\mathrm{C}: \mathrm{N}$ ratio $(\mathrm{r}=0.05)$. Models that simulate agronomic scenarios ${ }^{36-38}$ often describe the biochemical quality of crop residues only by their relative $\mathrm{C}$ to $\mathrm{N}$ contents (C:N ratio). Indeed, the most common criterion of quality used to predict mass loss or $\mathrm{N}$ mineralization during the decomposition of crop residues is the $\mathrm{C}: \mathrm{N}$ ratio of the plant material..$^{39}$ However, this ratio does not account for the availability of $\mathrm{C}$ and $\mathrm{N}$, which is often essential to understand the decomposition kinetics. ${ }^{40}$ Many studies have aimed to find other biochemical characteristics to predict the decomposition of crop residues while others have shown that the initial content of residue $\mathrm{N}^{41}{ }^{4}$ lignin ${ }^{42}$ and soluble $\mathrm{C}$ concentration ${ }^{43}$ are useful indicators of residue quality. Our results confirms the findings of other reports regarding the uncertainty of the absolute effect of the $\mathrm{C}: \mathrm{N}$ ratio on the residue decomposition process. ${ }^{44}$

Demand for $\mathrm{N}$ in wheat is lowest in winter but it increases quickly after stem elongation and decreases gradually after flowering. ${ }^{45}$ In the present study, based on the analysis of tissues in the first year, the highest leaf + stem $\mathrm{N}$ content was related to anthesis. In addition, the values decreased in all treatments due to remobilization to plant reproductive organs from anthesis onward $(\mathrm{N}$ remobilization ranged from 68 to 74\%). Plant N demand increased as growth stage progressed (stem elongation, booting, anthesis, and grain filling) because $\mathrm{N}$ is needed for the development and growth of reproductive organs and for increasing grain protein. Yield components are affected by both the amount of $\mathrm{N}$ and also the release period of N. ${ }^{45}$

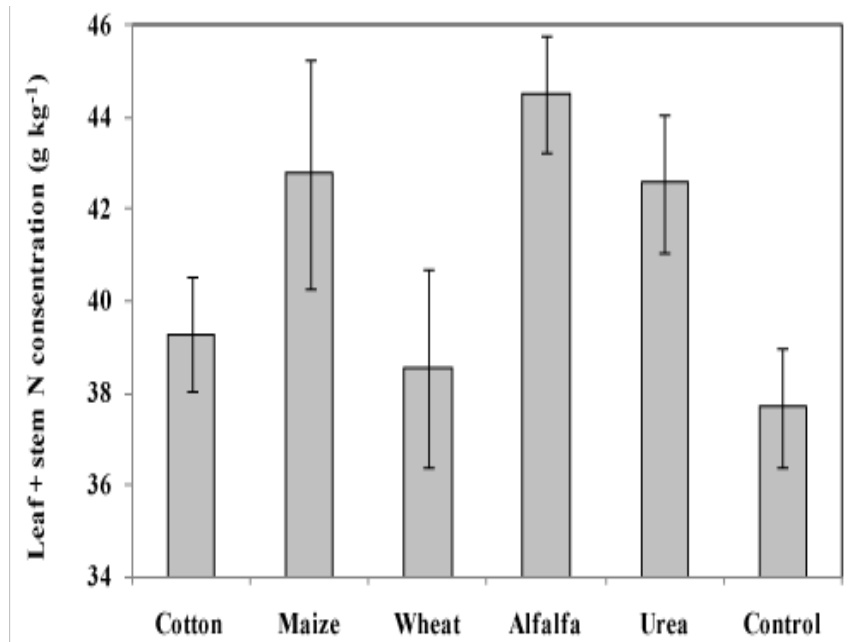

Figure 2 Leaf + stem nitrogen concentration $\left(\mathrm{g} \mathrm{kg}^{-1}\right)$ under different crop residues (2008-2009). Vertical bars show standard error.

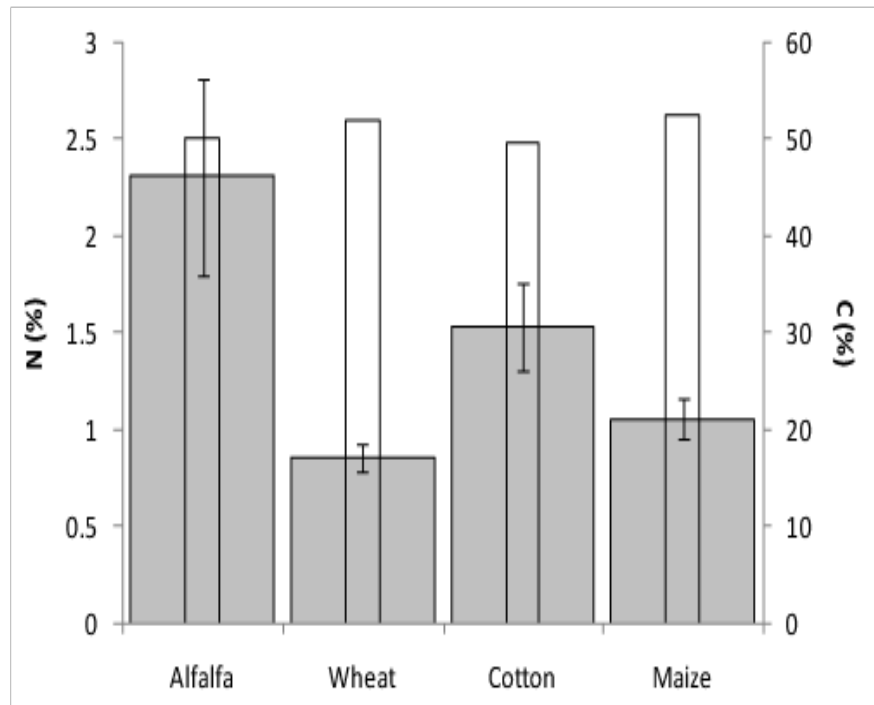

Figure 3 Carbon and nitrogen content (\%) in alfalfa, wheat, cotton and maize residues (grey bars show $\mathrm{N}$ content of residues, white bars show $\mathrm{C}$ content) vertical bars show standard error for $\mathrm{N}$ content.

According to Woolfolk et al. ${ }^{46} \mathrm{~N}$ concentration in the stem and growth points of wheat and grain was 51 and $104 \mathrm{~g} \mathrm{~kg}^{-1}$, respectively and since the greatest portion of grain $\mathrm{N}$ is provided as remobilization from growth tissues, grains are the major source for $\mathrm{N}$ accumulation relative to other plant organs.

$\mathrm{N}$ concentration in plant tissue during tillering and stem elongation in all residues in the first year was around the threshold limit (28.5$40.25 \mathrm{~g} \mathrm{~kg}^{-1}$ ), Enough limit of $\mathrm{N}$ in wheat tissue and based on $\mathrm{N}$ 
concentration in tillering and stem elongation stage has been reported (43-52 and 36-44 $\mathrm{g} \mathrm{kg}^{-1}$ tissue) respectively [47]. Implying that despite using residues in soil and prohibiting $\mathrm{N}$ immobilization, the $\mathrm{N}$ demand of plants has not yet been fulfilled.

Even though $100 \mathrm{~kg} \mathrm{~N} \mathrm{ha}^{-1}$ was added to avoid $\mathrm{N}$ immobilization during the process of decomposition of wheat residues, it did not perform well over both years. It is not advisable to use the wheat residue with too high a $\mathrm{C}: \mathrm{N}$ ratio (60.47) as it does not allow the residue to be used as an efficient internal-field input. Wheat grain yield might have been highest in both years since the alfalfa residue can provide and supply more $\mathrm{N}$ to plants during the grain-filling period $(74.1 \mathrm{~kg} \mathrm{~N}$ ha $^{-1}$ ) (Table 3). Gregory ${ }^{48} \&$ Pare et al., ${ }^{49}$ also reported increased grain yield in cereals as a result of sowing on leguminous residues instead of frequent cereal sowing. The lower wheat grain yield (Table 2) when wheat residue was used was attributed to a lower contribution of $\mathrm{N}$ from this residue $\left(54.39 \mathrm{~kg} \mathrm{~N}^{-1}\right)$ (Table 3). Allelopathy is also likely to affect this outcome, but has not been considered here.

In contrast, alfalfa as a legume crop showed the lowest $\mathrm{C}: \mathrm{N}$ ratio among the crop residues tested and could be used as an internal input to add $\mathrm{N}$ to soil to fulfill the wheat $\mathrm{N}$ demand. The maximum yield gap between residues and control treatment $\left(1.7\right.$ ton ha $\left.{ }^{-1}\right)$ was attributed to alfalfa while corresponding values for cotton, wheat, maize and urea were $0.4,0.6,0.8$ and 1.2 ton $^{-1} \mathrm{~h}^{-1}$, respectively while these values for the second year (2009-10) were 0.9, 0.7, 1.1, and 0.4 ton $\mathrm{ha}^{-1}$, respectively. The highest $\mathrm{N}$ concentration in leaves and stems was also seen in wheat plants cultivated with alfalfa residue; this was accompanied by the highest nitrate + ammonia concentration in the soil. This demonstrates that the incorporation of alfalfa residue into the soil improved both soil $\mathrm{N}$ supply and capture by wheat. It is undeniable that a higher accumulation of $\mathrm{N}$ in leaves of wheat plants that accompanied the increase in soil $\mathrm{N}$ could be attributed to the higher $\mathrm{N}$ content of alfalfa residues than by other residues ( $\mathrm{N}$ content in alfalfa was $2.3 \%$ ) (Figure 3 ). This is in agreement with results obtained by Raiesi ${ }^{50}$ who reported that wheat and alfalfa residues showed significant differences in most litter quality parameters as well as in $\mathrm{C}$ and $\mathrm{N}$ turnover rates. Plant residues with a higher quality (high $\mathrm{N}$ contents; low lignin, cellulose and polyphenol contents; low ratios of $\mathrm{C} / \mathrm{N}$ and lignin/ $\mathrm{N}$ ) often show high decomposition and $\mathrm{N}$ mineralization rates. Residue mass loss is positively affected by the initial $\mathrm{N}, \mathrm{P}^{51}$ and $\mathrm{K}^{52}$ contents and negatively affected by the $\mathrm{C}: \mathrm{N}$ ratio. Nitrogen mineralization proceeds more rapidly in residues rich in N. ${ }^{53}$

For all residues, except for wheat, the amount of urea added was $<90 \mathrm{~kg} . \mathrm{ha}^{-1}$ (i.e., less than the urea treatment) implying that residue treatments were good because they required the consumption of less synthetic fertilizer (Figure 4). Moreover, all residues resulted in higher yield than the control treatment (ranging from 0.4 for cotton to 1.7 ton $\mathrm{ha}^{-1}$ for alfalfa), emphasizing the comparable N-use efficiency of residue-treated plots, especially for alfalfa. Although only alfalfa residue resulted in better yield than urea, all residue-treated plots showed higher yield than the control treatment (Figure 4). The rate of increment in yield per $1 \mathrm{~kg}$ of added $\mathrm{N}$ compared with the control treatment for alfalfa, wheat, maize and cotton residues was $29.14,6$, 10.66 and $6.04 \mathrm{~kg}$ grain $\mathrm{ha}^{-1} \mathrm{~kg}^{-1} \mathrm{~N}$ (added as urea); this value for urea was $13.33 \mathrm{~kg}$ grain ha- $\mathrm{kg}^{-1} \mathrm{~N}$. Therefore, the use of alfalfa residue was best (yield-wise) although wheat and cotton residues did not perform well.

Soil analysis of total nitrate and ammonia concentration during the growing season in the first year revealed that the maximum release of $\mathrm{N}$ in alfalfa-treated plots was completely different from that of other treatments. The highest values of $\mathrm{N}$ released during the wheat growing season occurred between tillering and stem elongation stages for alfalfa and between anthesis and physiological maturity for the other residues. However, the value for all residues decreased during the second year (data not shown) because the $\mathrm{N}$ pool gradually became exhausted over time. This reveals that different residues have different rates of release; alfalfa might have released $\mathrm{N}$ more slowly relative to crop demand.

Our results show that alfalfa was the best treatment compared to urea from both a quantitative (amount of $\mathrm{N}$ released) and a qualitative (release period) perspective of residue management to improve soil fertility with an emphasis on N. However, the use of other residues is likely to result in conservative yield and benefits.

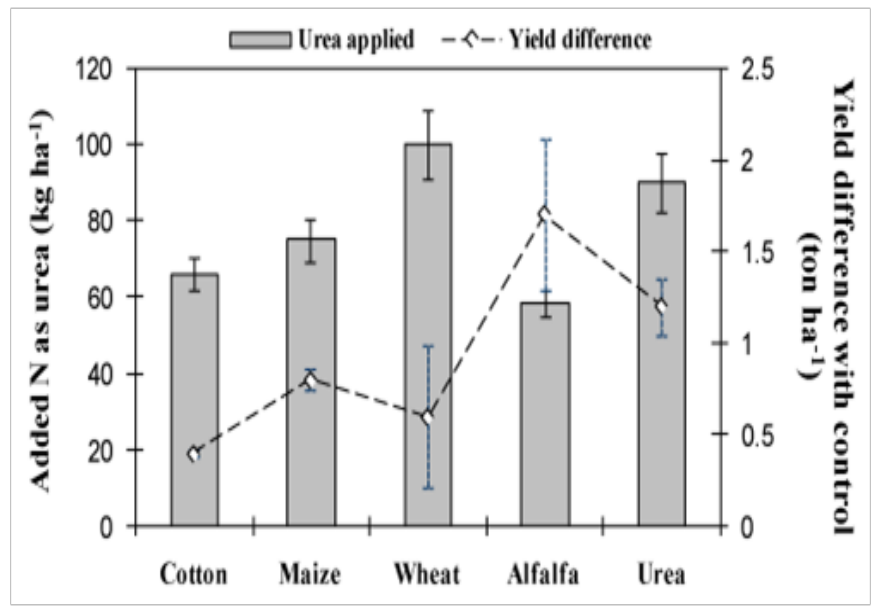

Figure 4 Relationship between added $\mathrm{N}$ as urea and yield difference with control in studied crop residues treatments. Solid and dashed vertical bars show standard errors for added $\mathrm{N}$ and yield difference, respectively.

\section{Acknowledgements}

None.

\section{Conflict of interest}

The author declares no conflict of interest.

\section{References}

1. Kumar K, Goh KM. Crop residues and management practices: effects on soil quality, soil nitrogen dynamics, crop yield, and nitrogen recovery. Adv Agron. 1999;68:197-319.

2. Blanco-Canqui H, Lal R. Crop residue removal impacts on soil productivity and environmental quality. Crit Rev Plant Sci. 2009;28(3):139163.

3. Lal R. Is crop residue a waste? $J$ Soil Water Conserv. 2004;59(6):136A-139A.

4. Cruse RM, Herndl CG. Balancing corn stover harvest for biofuels with soil and water conservation. J Soil Water Conserv. 2009;64(4):286-291.

5. Johnson JMF, Karlen DL, Andrews SS. Conservation considerations for sustainable bioenergy feedstock production: If, what, where, and how much? J Soil Water Conserv. 2010;65(4):88A-91A.

6. Al-Sheikh A, Delgado JA, Barbarick K, et al. Effects of potato-grain rotations on soil erosion, carbon dynamics and properties of rangeland sandy soils. Soil Till Res. 2005;81(2):227-238. 
7. Delgado JA, Dillon MA, Sparks RT, et al. A decade of advances in cover crops: Cover crops with limited irrigation can increase yields, crop quality, and nutrient and water use efficiencies while protecting the environment. J Soil Water Conserv. 2007;62(5):110A-117A.

8. Lal R. A modest proposal for the year 2001: we can control greenhouse gases and feed the world with proper soil management. $J$ Soil Water Conserv. 2000;55(4):429-433.

9. Ghimire R, Adhikari KR, Chen Z, et al. Soil organic carbon sequestration as affected by tillage, crop residue and nitrogen application in rice-wheat rotation system. Paddy Water Environ. 2012;10(2):95-102.

10. Sall SN, Masse D, Bernhard-Reversat F, et al. Microbial activity during the early stage of laboratory decomposition of tropical leaf litters: the effect of interactions between litter quality and exogenous inorganic nitrogen. Biol Fert Soils. 2003;39(2):103-111.

11. Jensen LS, Salo T, Palmason F, et al. Influence of biochemical quality on $\mathrm{C}$ and $\mathrm{N}$ mineralization from a broad variety of plant materials in soil Plant Soil. 2005;273(1-2):307-326.

12. Smith SJ, Sharpley AN. Soil nitrogen mineralization in the presence of surface and incorporated crop residues. Agron J. 1990;82(1):112-116.

13. Pang XP, Letey J. Organic farming: challenge of timing nitrogen availability to crop nitrogen requirements. Soil Sci Soc Am J. 2000;64:247253.

14. Kwabiah AB, Stoskopf NC, Palm CA, et al. Phosphorus availability and maize response to organic and inorganic fertilizer inputs in a short term study in Western Kenya. Agr Ecosyst Environ. 2003;95(1):49-59.

15. Kuo S, Jellum EJ. Influence of winter cover crop and residue management on soil nitrogen availability and corn. Agron J. 2002;94(3):501508 .

16. Kumar K, Goh KM. Management practices of antecedent leguminous and non-leguminous crop residues in relation to winter wheat yield, nitrogen uptake, soil nitrogen mineralization and simple nitrogen balance. Eur J Agron. 2002;16(4):295-308.

17. Tejada M, Gonzalez JL. Effects of the application of a compost originating from crushed cotton gin residues on wheat yield under dry land conditions. Eur J Agron. 2003;19(2):357-368.

18. Surekha K, Kumari AP, Narayana Reddy M, et al. Crop residue management to sustain soil fertility and irrigated rice yields. Nutr Cycling Agroecosys. 2003;67(2):145-154.

19. Rachid M. Effects of residue management and cropping systems on wheat yield stability in a semiarid Mediterranean clay soil. Am J Plant Sci. 2011;2(2):202-216.

20. Kouyate Z, Franzluebbers K, Juo ASR, et al. Tillage, crop residue, legume rotation, and green manure effects on sorghum and millet yields in the semiarid tropics of Mali. Plant Soil. 2000;225(1-2):141-151.

21. Shafi M, Bakht J, Jan MT, et al. Soil C and N dynamics and maize (Zeamays) yield as affected by cropping systems and residue management in Northwestern Pakistan. Soil Till Res. 2007;94(2):520-529.

22. Schreiber MM. Influence of tillage crop rotation and weed management on giant foxtail population dynamics and corn yield. Weed Sci. 1992;40(4):645-653.

23. Lund MG, Carter PR, Oplinger ES. Tillage and crop rotation affect corn, soybean and winter wheat yields. J Prod Agric. 1993;6(2):207-213.

24. Wicks GA, Crutchfield DA, Burnside OC. Influence of wheat straw mulch and metoalochlor on corn growth and yield. Weed Sci. 1994;42(1):141-147.

25. Cochran VL, Elliot LF, Papendick RJ. Effect of crop residues management and tillage on water use efficiency and yield of winter wheat Agron J. 1982;4(6):929-933.
26. Kamkar B, Movahedi Naeini AR, Safahani AR. The effects of different litters on dynamism of nitrate and ammonia contents of soil and related effects on wheat yield. Research Report.Gorgan University of Agricultural Science and Natural Resources (GUASNR); 2010.

27. Rasmussen PE, Rickman RW, Klepper BL. Residue and fertility effects on yield of no- till wheat. Agron J. 1997;89:563-567.

28. Rasmussen PE, Rohde CR. Long- term tillage and nitrogen fertilization effect on organic nitrogen and carbon in semi-arid soil. Soil Sci Soc Am J. 1988;52:1114-1117.

29. Soltani A, Torabi B, Ghaleshi S, et al. Analysis Wheat yield constraint in Gorgan with comparative performance analysis (CPA) method. Research Report. Gorgan University of Agricultural Sciences and Natural Resources; 2010. 65 p.

30. Walkley A, Black IA. An examination of the degtjareff method for determining soil organic matter and a proposed modification of the chromic acid titration method. Soil Sci. 1934;37:29-38.

31. Bremner JM. Nitrogen-total. Methods of soil analysis. Part 3- Chemical Methods. SSSA Book Series No. 5. D. L. Sparks et al. editors. Madison, WI: Soil Science Society of America, Inc; 1996. p. 1085-1121.

32. Barbarick KA. Colorado State University. Organic materials as nitrogen fertilizers; 2010

33. Zadox JC, Chang TT, Konzak CF. A decimal code for the growth of cereals. Weed Res. 1974;14(6):415-421.

34. SAS Inst Inc. SAS/STAT Users Guide, Release 6.03 edition. Cary, NC, USA: SAS Institute Inc; 1998. 1028 p.

35. Whitmor AP, Handayanto E. Simulating the mineralization of $\mathrm{N}$ from crop residues in relation to residue quality. In: Cadish $\mathrm{G}$, et al. editors. Driven by nature-plant litter quality and decomposition. CAB International Wallingford; 1997. p. 337-348.

36. Probert ME, Dimes JP, Keating BA, et al. Apsim's water and nitrogen modules and simulation of the dynamics of water and nitrogen in fallow systems. Agr Syst. 1998;56(1):1-28.

37. Brisson N, Mary B, Ripoche D, et al. STICS: a generic model for the simulation of crops and their water and nitrogen balances. I. Theory and parameterization applied to wheat and corn. Agron J. 1998;18(56):311-346

38. Ghimire R, Shah SC, Dahal KR, et al. Soil organic carbon sequestration by tillage and crop residue management in rice-wheat cropping system of Nepal. J Inst Agric Animal Sci. 2008;29:21-26.

39. Vanlauwe B, Nwoke OC, Sanginga N, et al. Impact of residues quality on the $\mathrm{C}$ and $\mathrm{N}$ mineralization of leaf and root residues of three agroforestry species. Plant Soil. 1996;83(2):221-231.

40. Recous S, Roubin D, Darwis S, et al. Soil inorganic N availability: effect on maize decomposition. Soil Biol Biochem. 1995;27(12):1529-1538.

41. Frankenberger WTJ, Abdelmagid HM. Kinetic parameters of nitrogen mineralization rates of leguminous crops incorporated into soil. Plant Soil. 1985;87(2):257-271

42. Muller MM, Sundman V, Soininvaara O, et al. Effects of chemical composition on the release of $\mathrm{N}$ from agricultural plant material decomposing in soil under field conditions. Biol Fert Soils. 1988;6(1):78-83.

43. Oglesby KA, Fownes JH. Effects of chemical composition on nitrogen mineralization from green manures of seven tropical leguminous trees. Plant Soil. 1992;143(1):127-132.

44. Chaves B, Neve SDe, Hofman G, et al. Modelling the N mineralization of vegetable root residues and green manures using the (bio) geochemical composition. Comm Agric Appl Biol Sci. 2002;67:51-54. 
45. Satorre EH, Slafer GA. Wheat: ecology and physiology of yield determination. New York: The Haworth Press; 1999. 503 p.

46. Woolfolk CW, Raun WR, Johnson GV, et al. Influence of late season foliar nitrogen application on yield and grain nitrogen in winter wheat. Agron J. 2002;94:429-434.

47. Fageria NK, Baligar VC. Enhancing nitrogen use efficiency in crop plants. Adv Agron. 2005;88:97-185.

48. Gregory PJ. Alternative crops for duplex soil: growth and water use of some cereal legume and oilseed crops and pastures. Aust J of Agric Res. 1998;49(1):21-32.

49. Pare T, Chalifour FP, Bourassa J, et al. Previous legumes and N- fertilizer effects on mineral concentration and uptake by forage corn. Cana J Plant Sci. 1993;73(2):461-476.
50. Raiesi F. Carbon and $\mathrm{N}$ mineralization as affected by soil cultivation and crop residue in a calcareous wetland ecosystem in Central Iran. $\mathrm{Agr}$ Ecosyst Environ. 2006;112(1):13-20.

51. Xu X, Hirata E. Decomposition patterns of leaf litter of seven common canopy species in a subtropical forest: N and P dynamics. Plant Soil. 2005;273(1-2):279-289.

52. Mendonça ES, Stott DE. Characteristics and decomposition rates of pruning residues from a shaded coffee system in Southeastern Brazil. Agrofor Syst. 2003;57(2):117-125.

53. Trinsoutrot I, Recous S, Bentz B, et al. Biochemical quality of crop residues and carbon and nitrogen mineralization kinetics under non limiting nitrogen conditions. Soil Sci Soc Am J. 2000;64(3):918-926. 